\title{
The Relationship between Smoking, Socioeconomic Status and Grip Strength among Community-dwelling Elderly Men in Korea: Hallym Aging Study
}

\author{
ShanAi Quan ${ }^{1,2}$, Jin-Young Jeong ${ }^{3}$, Dong-Hyun Kim ${ }^{1,2}$ \\ ${ }^{1}$ Department of Social and Preventive Medicine, Hallym University College of Medicine, Chuncheon; ${ }^{2}$ Hallym Research Institute of Clinical \\ Epidermiology, Hallym University College of Medicine, Chuncheon; ${ }^{3}$ Korea Health Promotion Foundation, Seoul, Korea
}

OBJECTIVES: Low grip strength is associated with decline in bone mineral density (BMD) and increased risk of spine fracture among the elderly. Smoking, a major factor determining BMD, is also known to have an indirect effect on bone loss. This study investigated whether smoking is associated with grip strength in the community-dwelling elderly in Korea.

METHODS: This study was an outcome of the second of three waves of the Hallym Aging Study from January to May 2007, a population-based study of Koreans aged 45 years and upwards dwelling in Chuncheon. Its 218 subjects comprised men aged 65 years or over. They were evaluated at a general hospital for socioeconomic status, smoking history, and various clinical measures including grip strength.

RESULTS: Grip strength was higher in non-, ex-, and current smokers $(33.7 \mathrm{~kg}, 30.6 \mathrm{~kg}$, and $29.3 \mathrm{~kg}$, respectively). Current smoking was found to increase the risk of decreased grip strength (adjusted odds ratio [aOR], 4.58; $95 \%$ confidence interval [CI],1.31 to 16.04) compared with non-smoking, after adjustment for potential covariates including socioeconomic status. After adjustment for smoking effect, education of fewer than six years and monthly income of fewer than 500,000 Korean won increased the risk of decreased grip strength compared with education of more than six years (aOR, 2.88; 95\% CI, 1.08 to 7.66) and monthly income of more than $1,500,000$ Korean won (aOR, 2.86; $95 \%$ CI, 1.08 to 7.54).

CONCLUSIONS: These results showed that current smoking, low education and low income were independent risk factors for decreased grip strength among elderly men in Korea.

KEY WORDS: Elderly men, Hand strength, Smoking, Socioeconomic

\section{INTRODUCTION}

Physical functioning represents an integrated marker of aging, influenced by a broad array of physiological and clinical char-

\footnotetext{
Correspondence: Dong-Hyun Kim, MD, PhD

Department of Social and Preventive Medicine, Hallym University College of Medicine, 39 Hallymdaehak-gil, Chuncheon 200-702, Korea

Tel: +82-33-248-2660, Fax: +82-33-256-1675, E-mail: dhkims@hallym.ac.kr

Received: Nov 12, 2012, Accepted: Jan 11, 2013, Published: Feb 18, 2013

This article is available from: http://e-epih.org/.

(C) 2013, Korean Society of Epidemiology

(C) This is an open-access article distributed under the terms of the Creative Commons Attribution License (http://creativecommons.org/licenses/by/3.0/), which permits unrestricted use, distribution, and reproduction in any medium, provided the original work is properly cited.
}

acteristics interacting with behavior and the social environment [1]. In old age, decreased muscle strength predisposes people to functional limitations and disability [2]. Older people had less appendicular skeletal muscle than younger, the decline in muscle mass of $-0.4 \mathrm{~kg} /$ decade in women and $0.8 \mathrm{~kg} /$ decade in men starting at the age of 20 [3]. According to Rantanen et al. [4], the intra-individual strength changes over time were significant in all ages. Muscle strength was found to influence life-span. Those who have higher grip strength during midlife remain stronger than others in old age [4] and people who have greater muscle strength during midlife then have a lower risk of becoming disabled because of their greater ability to maintain that strength regardless of chronic conditions that may develop [5]. Grip strength is known as a good predictor of unhealthy 
outcomes such as mortality and may indicate subclinical disease, which later develops into clinical disease [5] and functional limitation [6]. Grip strength is also known to be correlated with bone mineral density (BMD) in middle-aged men [7]. Agerelated bone loss is reported to be associated with decreased BMD [8] and with weakened muscle strength [9]. Grip strength tests are convenient, safe, and reliable, and do not require large or expensive equipment [10]. Consequently, grip strength has been used as an indicator of overall muscle strength in many population studies [11].

Smoking is one of the major components determining BMD [12]. Smoking is associated with lower BMD of neck and spine in both male and female elderly and is known to increase hip fracture rates compared with nonsmokers [10]. In Ward and Klesges [11] study, absolute effects at most bone sites were greatest for current smokers compared with those who had never smoked.

Elderly with lower socioeconomic status (SES) according to educational attainment, income, and occupation have significantly higher morbidity and mortality than individuals with higher SES $[13,14]$. A study has shown that SES is related to mobility disability in later life [15]. Levels of education and/or income have also been significantly associated with decreased physical function $[14,16]$. Studies have found that higher SES is associated with higher BMD at total hip [17], femoral neck [18], and spine [19].

This study was conducted to elucidate whether smoking and social economic status are associated with grip strength in community-dwelling elderly men in Korea.

\section{METHODS AND MATERIALS}

\section{Subjects}

Subjects in this analysis were recruited in the Hallym Aging Study (HAS). HAS is a population-based study of Koreans aged 45 years or older dwelling in Chuncheon. The first wave began in 2003 and an in-depth clinical study was started in 2004. The city was divided into 1,408 areas based on the 2000 census and 200 were randomly selected. The first-wave participants were selected by systematic sampling: $30 \%$ of subjects were sampled from individuals aged 45 to 64 and $70 \%$ were sampled from individuals aged 65 years or older. Participants of the first-wave survey in 2003 numbered 1,520. Among them, 918 had participated in an in-depth clinical study in 2004. A physical performance test was administered in the second wave of the clinical study in 2007, whereby the subjects were limited to elderly men aged 65 years or older, excluding 93 individuals who did not test for hand grip or had a score of activities of daily living score $>10$. Finally, 218 subjects were available for

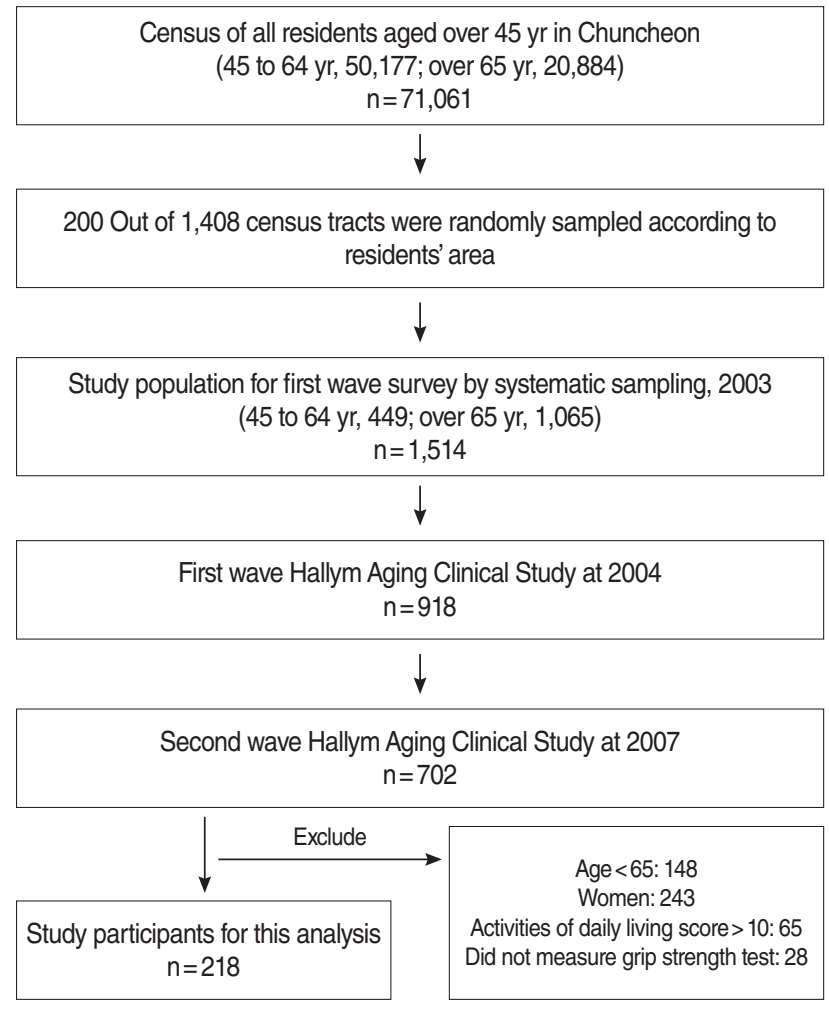

Figure 1. Flow chart of Hallym Aging Study.

the final analysis (Figure 1).

Demographic characteristics included age, marital status, average monthly income and education. Age was divided into 65 to 69,70 to 74,75 to 79 , and 80 years and older groups. Monthly income was divided into fewer than 500,000, 500,000 to $1,490,000,1,500,000$ to $2,990,000$ and more than $3,000,000$ Korean won (1,000 Korean won is about 1.00 US dollar). Education level was divided into 0 to 6,6 , and more than 6 years. Smoking status was categorized as current smoker, past smoker, and never.

\section{Test of grip strength}

To test grip strength, each participant sat on a chair and put one arm on the table in front of him. The wrist and forearm were in neutral anatomical position and the arm was flexed at $90^{\circ}$. In this position, the participants were encouraged to exert their maximal grip [20]. Grip strength was measured for both hands and every hand measured twice. We checked the main hand, let participants rest for 15 seconds before the second test, then swapped hands. Grip strength measurement was performed with the digital dynamometer (TKK-5401; Takei, Tokyo, Japan) in kilograms, and the better numerical value of the main hand was used in the analysis. 


\section{Statistical analysis}

Characteristics of study participants according to grip strength were expressed by mean with standard deviation for continuous variables and by number with percentages for categorical variables. Least-squares mean for grip strength according to smoking status was calculated by the PROC GLM program (SAS Inc., Cary, NC, USA). Since some factors, such as age, lifestylerelated factors, genetic background, physical activities, and previous medical diseases, may affect grip strength decline [21], odds ratios (OR) for risk of decline of grip strength were computed by logistic regression analysis after adjustment for potential covariates. Grip strength was divided into low and high groups by median. Data analyses were performed with the SAS version 9.1 (SAS Inc., Cary, NC, USA).

\section{RESULTS}

Table 1 shows overall characteristics of study subjects according to level of grip strength. The subjects with high grip strength were younger, more educated, more likely to be smokers, and more likely to participate in regular exercise than those with low grip strength (Table 1). The grip strength of nonsmokers adjusted for age, smoking status, level of education, and obesity was higher than that of past and current smokers (Figure 2).
After adjustment for age, education, income, regular excise, and body mass index, the risk of decreased grip strength gradually increased among current smokers (aOR, 4.5; 95\% CI, 1.10 to 9.17), those with low educational attainment (aOR, 2.88; $95 \%$ CI, 1.08 to 7.66 ) and those with low monthly income (aOR, 2.86; 95\% CI, 1.08 to 7.54), compared with non-smokers, those with high educational attainment, and those with high monthly income, respectively (Table 2).

\section{DISCUSSION}

Current smokers were found to have higher risk of decreased grip strength compared with non-smokers. Education and in-

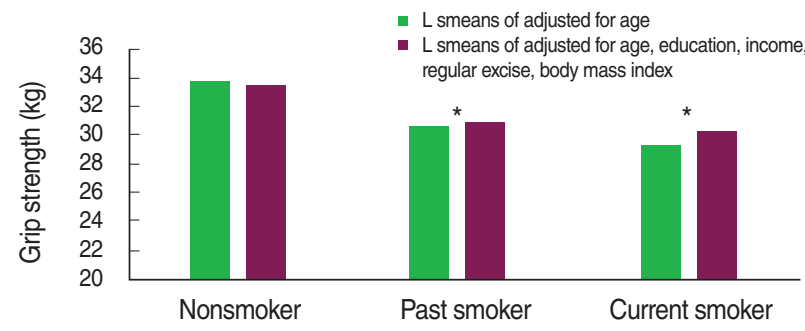

Figure 2. Grip strength according to smoking status among men. ${ }^{*} \mathrm{p}<0.05$ compared to nonsmokers.

Table 1. Characteristics according to grip strength at baseline

\begin{tabular}{|c|c|c|c|c|}
\hline \multirow{2}{*}{ Variables } & & \multicolumn{3}{|c|}{ Grip strength* } \\
\hline & & \multirow{2}{*}{$\operatorname{Low}(n=111)$} & \multirow{2}{*}{$\frac{\text { High }(n=107)}{72.2 \pm 4.0}$} & \multirow{2}{*}{$\frac{\text { p-value }}{<0.001^{\dagger}}$} \\
\hline Age (yr) & & & & \\
\hline \multirow[t]{3}{*}{ Education (yr) } & $0-6$ & $37(33.3)$ & $13(12.2)$ & $<0.001^{\ddagger}$ \\
\hline & 6 & $37(33.3)$ & $27(25.2)$ & \\
\hline & $>6$ & $37(33.3)$ & $67(62.6)$ & \\
\hline \multirow[t]{3}{*}{ Income (10,000 Korean won) } & $<50$ & $29(29.0)$ & $17(17.2)$ & $<0.001^{\ddagger}$ \\
\hline & $50-149$ & $50(50.0)$ & $27(27.3)$ & \\
\hline & $\geq 150$ & $21(21.0)$ & $55(55.6)$ & \\
\hline \multicolumn{2}{|l|}{ Married and living together } & $96(86.5)$ & $96(89.7)$ & $0.46^{\ddagger}$ \\
\hline \multicolumn{2}{|l|}{ Regular exercise } & $24(21.6)$ & $43(40.2)$ & $0.003^{\ddagger}$ \\
\hline \multirow[t]{3}{*}{ Smoking status } & None & $11(9.9)$ & $27(25.2)$ & $0.005^{\ddagger}$ \\
\hline & Past & $67(60.4)$ & $61(57.0)$ & \\
\hline & Current & $33(29.7)$ & $19(17.8)$ & \\
\hline \multirow[t]{3}{*}{ Alcohol drinking } & None & $22(19.8)$ & $30(28.0)$ & $0.35^{\ddagger}$ \\
\hline & Past & $32(28.8)$ & $29(27.1)$ & \\
\hline & Current & $57(51.4)$ & $48(44.9)$ & \\
\hline \multicolumn{2}{|l|}{ Hypertension } & $81(73.6)$ & $87(82.1)$ & $0.14^{\ddagger}$ \\
\hline \multicolumn{2}{|l|}{ Diabetes } & $20(18.4)$ & $25(23.4)$ & $0.40^{\ddagger}$ \\
\hline \multicolumn{2}{|l|}{ Body mass index $\left(\mathrm{kg} / \mathrm{m}^{2}\right)$} & $23.4 \pm 3.1$ & $24.5 \pm 2.8$ & $0.01^{\dagger}$ \\
\hline \multicolumn{2}{|l|}{ Total cholesterol (mg/dL) } & $182.7 \pm 37.6$ & $184.3 \pm 39.2$ & $0.77^{\dagger}$ \\
\hline \multicolumn{2}{|c|}{ Triglyceride (mg/dL) } & $141.5 \pm 80.7$ & $140.8 \pm 89.4$ & $0.52^{\S}$ \\
\hline \multicolumn{2}{|c|}{ High density lipoprotein cholesterol (mg/dL) } & $49.7 \pm 13.5$ & $50.6 \pm 37.5$ & $0.29 \S$ \\
\hline
\end{tabular}

Values are presented as mean \pm SD or number (\%).

${ }^{*}$ Cut point of grip strength for men is $31.4 \mathrm{~kg}$; ${ }^{\top}$ Two sample t-test; ${ }^{~}$ Chi-squared test; ${ }^{\$}$ Wilcoxon's rank sum test. 
Table 2. Effect of smoking status on the risk of low grip strength among elderly men

\begin{tabular}{|c|c|c|c|}
\hline & & Grip s & strength* \\
\hline & & $\begin{array}{l}\text { Age-adjusted } \\
\text { OR }(95 \% \mathrm{Cl})\end{array}$ & $\begin{array}{c}\text { Multivariable-adjusted } \\
\mathrm{OR}^{\dagger}(95 \% \mathrm{Cl})\end{array}$ \\
\hline Age (yr) & $65-69$ & 1.0 & 1.0 \\
\hline & $70-74$ & $1.32(0.58-3.03)$ & $1.21(0.45-3.20)$ \\
\hline & $>75$ & $5.83(2.40-14.19)$ & $7.04(2.44-20.32)$ \\
\hline Smoking status & None & 1.0 & 1.0 \\
\hline & Past & $3.93(1.50-10.27)$ & $2.18(0.74-6.40)$ \\
\hline & Current & $9.60(3.17-29.06)$ & $4.58(1.31-16.04)$ \\
\hline Education (yr) & $0-6$ & 1.0 & 1.0 \\
\hline & 6 & $2.10(1.02-4.28)$ & $1.36(0.60-3.07)$ \\
\hline & $>6$ & $5.93(2.51-14.0)$ & $2.88(1.08-7.66)$ \\
\hline Income & $\geq 150$ & 1.0 & 1.0 \\
\hline (10,000 Korean won) & $50-149$ & $5.55(2.62-11.76)$ & $4.11(1.80-9.35)$ \\
\hline & $<50$ & $4.76(2.10-11.30)$ & $2.86(1.08-7.54)$ \\
\hline
\end{tabular}

$\mathrm{OR}$, odds ratio; $\mathrm{Cl}$, confidence interval.

${ }^{*}$ Cut point of grip strength for men is $31.4 \mathrm{~kg}$; ${ }^{\dagger}$ Adjusted for age, education, income, regular excise, body mass index smoking.

come also affected the risk of the decline of grip strength among the elderly men in this study.

Hands have many physiological and anatomical changes associated with aging. Impaired hand abilities are observed among the elderly with metabolic and skeletal diseases such as osteoarthritis and rheumatoid arthritis [22]. Starting in middle age, men lose approximately a fifth of BMD over their lifetimes [23]. Smokers were reported to have less bone mass at all measured sites, and smoking cessation had a beneficial effect on bone mass as past smokers had an intermediate bone phenotype compared with either lifelong non-smokers or current smokers [24]. Smoking is significantly associated with BMD in middleaged men $[25,26]$ since the nicotine from cigarettes is involved in the metabolism of calcium and vitamin D and affects bone health [27]. Smokers may have different taste perception, leading them to choose unhealthy food [28], and may take less exercise [29] compared with non-smokers. Kanis et al. [30] reported that current smoking was associated with a $25 \%$ increase in fracture risk compared with the risk in subjects who had never smoked. One study of elderly men and women reported grip strength can predict BMD of the proximal radius [31] and another study of athletes also reported that grip strength was a predictor of radial BMD [32].

Low income and low educational attainment can affect the risk of overall health and functional limitations among the elderly [33] and are known to be associated with lower levels of self-efficacy in specific behavioral domains [34]. High income and educational attainment are more likely to have a higher level of perceived control and thus situation-specific self-efficacy [35]. This means that higher socioeconomic status may increase the likelihood of individuals having the confidence nec- essary to attempt socially prescribed behavioral changes and having the resources necessary to ease the adoption process (e.g., time, money) [33]. Higher education may allow someone to access more knowledge on health, practice more healthy behaviors, have more employment opportunities, and earn higher income, which all affect health [36]. Income affects health in various ways, such as availability of material resources and health services [15].

Given the public health implications of smoking on bone health, it is important that this information be incorporated into smoking prevention and cessation efforts targeting the elderly [37]. Elderly people commonly have difficulties in terms of hand function and hand strength can affect simple everyday actions. Grip strength is a simple test and an important index of the body's muscle situation and can predict disability in the nearer future. Declining physical fitness as a natural aging process may not be completely prevented, however.

One of the strengths of this study is that the long-term effect of smoking on physical function and occurrence of chronic diseases can be assessed in a relatively short time through a test of grip strength, which can be regarded as a surrogate indicator predicting these health conditions. This study may not appropriate to demonstrate the effect of smoking on health outcomes directly since we observed them at the same time in this crosssectional study.

A limitation of this study is that there may be residual confounding owing to categorical variables such as smoking (non-, ex-, and current) and socioeconomic status. It is hard to exclude the possibilities of unknown confounders between groups with high and low grip strength. In addition, because participants in this study at least maintained their health, it was not representative of all elderly people, but the findings can be applied to healthy elderly people residing in the community.

Though we cannot change some factors such as age and education among the elderly, we can improve health behaviors such as smoking, and reverse or delay the process of decline of muscle strength.

\section{CONFLICT OF INTEREST}

The authors have no conflicts of interest to declare for this study.

\section{REFERENCES}

1. Sowers M, Tomey K, Jannausch M, Eyvazzadeh A, Nan B, Randolph J Jr. Physical functioning and menopause states. Obstet Gynecol 2007;110:1290-1296. 
2. Nagi SZ. An epidemiology of disability among adults in the United States. Milbank Mem Fund Q Health Soc 1976;54:439-467.

3. Gallagher D, Visser M, De Meersman RE, Sepúlveda D, Baumgartner RN, Pierson RN, et al. Appendicular skeletal muscle mass: effects of age, gender, and ethnicity. J Appl Physiol 1997;83:229-239.

4. Rantanen T, Masaki K, Foley D, Izmirlian G, White L, Guralnik JM. Grip strength changes over 27 yr in Japanese-American men. J Appl Physiol 1998;85:2047-2053.

5. Rantanen T, Guralnik JM, Foley D, Masaki K, Leveille S, Curb JD, et al. Midlife hand grip strength as a predictor of old age disability. JAMA 1999;281:558-560.

6. Bassey EJ. Measurement of muscle strength and power. Muscle Nerve 1997;20:44-46.

7. Choi YA, Park IS, Kim MJ, Kim KG, Kang YG, Lee HT, et al. The relationship between grip strength and radial BMD in middle aged men. J Korean Acad Fam Med 2001;22:1520-1530 (Korean).

8. Davis JW, Ross PD, Vogel JM, Wasnich RD. Age-related changes in bone mass among Japanese-American men. Bone Miner 1991;15: 227-236.

9. Nordström P, Thorsen K, Bergström E, Lorentzon R. High bone mass and altered relationships between bone mass, muscle strength, and body constitution in adolescent boys on a high level of physical activity. Bone 1996;19:189-195.

10. Slemenda CW, Christian JC, Reed T, Reister TK, Williams CJ, Johnston CC Jr. Long-term bone loss in men: effects of genetic and environmental factors. Ann Intern Med 1992;117:286-291.

11. Ward KD, Klesges RC. A meta-analysis of the effects of cigarette smoking on bone mineral density. Calcif Tissue Int 2001;68:259-270.

12. Wong PK, Christie JJ, Wark JD. The effects of smoking on bone health. Clin Sci (Lond) 2007;113:233-241.

13. Berkman CS, Gurland BJ. The relationship among income, other socioeconomic indicators, and functional level in older persons. J Aging Health 1998;10:81-98.

14. Berkman LF, Seeman TE, Albert M, Blazer D, Kahn R, Mohs R, et al. High, usual and impaired functioning in community-dwelling older men and women: findings from the MacArthur Foundation Research Network on Successful Aging. J Clin Epidemiol 1993;46:1129-1140.

15. Melzer D, Izmirlian G, Leveille SG, Guralnik JM. Educational differences in the prevalence of mobility disability in old age: the dynamics of incidence, mortality, and recovery. J Gerontol B Psychol Sci Soc Sci 2001;56:S294-S301.

16. Coppin AK, Ferrucci L, Lauretani F, Phillips C, Chang M, Bandinelli $\mathrm{S}$, et al. Low socioeconomic status and disability in old age: evidence from the InChianti study for the mediating role of physiological impairments. J Gerontol A Biol Sci Med Sci 2006;61:86-91.

17. Wang MC, Dixon LB. Socioeconomic influences on bone health in postmenopausal women: findings from NHANES III, 1988-1994. Osteoporos Int 2006;17:91-98.

18. Lauderdale DS, Rathouz PJ. Does bone mineralization reflect economic conditions? An examination using a national US sample. Econ Hum Biol 2003;1:91-104.

19. del Rio Barquero L, Romera Baures M, Pavia Segura J, Setoain Quinquer J, Serra Majem L, Garces Ruiz P, et al. Bone mineral density in two different socio-economic population groups. Bone Miner 1992; 18:159-168.
20. Bassey EJ, Harries UJ. Effect of a test meal, without and with protein, on muscle and plasma free amino acids. Clin Sci (Lond) 1990; 79:331-337.

21. Carmeli E, Patish H, Coleman R. The aging hand. J Gerontol A Biol Sci Med Sci 2003;58:146-152.

22. Jansen CW, Niebuhr BR, Coussirat DJ, Hawthorne D, Moreno L, Phillip M. Hand force of men and women over 65 years of age as measured by maximum pinch and grip force. J Aging Phys Act 2008; 16:24-41.

23. Riggs BL, Wahner HW, Dunn WL, Mazess RB, Offord KP, Melton LJ 3rd. Differential changes in bone mineral density of the appendicular and axial skeleton with aging: relationship to spinal osteoporosis. J Clin Invest 1981;67:328-335.

24. Kiel DP, Zhang Y, Hannan MT, Anderson JJ, Baron JA, Felson DT. The effect of smoking at different life stages on bone mineral density in elderly men and women. Osteoporos Int 1996;6:240-248.

25. Bendavid EJ, Shan J, Barrett-Connor E. Factors associated with bone mineral density in middle-aged men. J Bone Miner Res 1996;11:11851190.

26. Hannan MT, Felson DT, Dawson-Hughes B, Tucker KL, Cupples LA, Wilson PW, et al. Risk factors for longitudinal bone loss in elderly men and women: the Framingham Osteoporosis Study. J Bone Miner Res 2000;15:710-720.

27. Kim SK, Yeon BY, Choi MK. Comparison of nutrient intakes and serum mineral levels between smokers and non-smokers. Korean J Nutr 2003;36:635-645 (Korean).

28. Subar AF, Harlan LC, Mattson ME. Food and nutrient intake differences between smokers and non-smokers in the US. Am J Public Health 1990;80:1323-1329.

29. Gambert SR, Schultz BM, Hamdy RC. Osteoporosis. Clinical features, prevention, and treatment. Endocrinol Metab Clin North Am 1995;24:317-371.

30. Kanis JA, Johnell O, Oden A, Johansson H, De Laet C, Eisman JA, et al. Smoking and fracture risk: a meta-analysis. Osteoporos Int 2005; 16:155-162.

31. Bevier WC, Wiswell RA, Pyka G, Kozak KC, Newhall KM, Marcus R. Relationship of body composition, muscle strength, and aerobic capacity to bone mineral density in older men and women. J Bone Miner Res 1989;4:421-432.

32. Tsuji S, Tsunoda N, Yata H, Katsukawa F, Onishi S, Yamazaki H. Relation between grip strength and radial bone mineral density in young athletes. Arch Phys Med Rehabil 1995;76:234-238.

33. Clark DO. Racial and educational differences in physical activity among older adults. Gerontologist 1995;35:472-480.

34. Gecas V. The social psychology of self-efficacy. Annu Rev Sociol 1989;15:291-316.

35. Rodin J, Schooler C, Schaie KW. Self-directedness: cause and effects throughout the life course. Hillsdale: L. Erlbaum Associates; 1990, p. 85-94.

36. Braveman P, Egerter S, Williams DR. The social determinants of health: coming of age. Annu Rev Public Health 2011;32:381-398.

37. Cornuz J, Feskanich D, Willett WC, Colditz GA. Smoking, smoking cessation, and risk of hip fracture in women. Am J Med 1999;106: 311-314. 